\title{
Explaining dissimilarities in macroinvertebrate assemblages among stream sites using environmental variables
}

\author{
Adriano S. Melo \\ Departamento de Ecologia, Instituto de Biociências, Universidade Federal do Rio Grande do Sul. Caixa postal 15007, \\ 91501-970 Porto Alegre, Rio Grande do Sul, Brasil. E-mail: adrimelo@ufrgs.br
}

\begin{abstract}
The relationship between community structure and environmental factors usually varies according to ecosystem type, group of organisms, and spatial scale. In this study I assessed whether dissimilarities among assemblages of stream macroinvertebrates are related to differences in environmental variables. Data consisted of macroinvertebrate samples of 10 stream sites during the dry season. Seven environmental variables were assessed. The relationship among dissimilarities in assemblage structure and dissimilarities in environmental variables was assessed using the BioEnv approach. Conductivity and measures related to stream size were the most important variables. However, part of the correlation with conductivity was due to the high value observed in a single stream site, which presented a relatively distinct macroinvertebrate fauna. There was an abrupt change in assemblage structure between $4^{\text {th }}$ and $5^{\text {th }}$ order streams. Although the study included a single $5^{\text {th }}$ order site and thus only weak generalizations are possible, this finding corroborates scattered evidence observed in previous studies. The finding that nearby sites may harbor distinct macroinvertebrate assemblages implies whole-catchment conservation strategies. As most of the remaining Atlantic Rain Forest is restricted to small fragments, restoration projects near fragments should be implemented so as to properly conserve lotic ecosystems.
\end{abstract}

KEY WORDS. Aquatic insects; BioEnv; Brazil; community structure; Neotropical Region.

Streams usually contain a diverse fauna of macroinvertebrates and in a single stream site more than 70 species can coexist (Melo \& Froenlich 2001a, b). Insects comprise most of the macroinvertebrate fauna either in terms of abundance and number of species (Allan 1995, BAPTISTA et al. 1998a, KIKUCHI \& Uieda 1998, Bueno et al. 2003, Buckup et al. 2007). Many insect orders are present in streams and together they usually represent around 95\% of the macroinvertebrate fauna in a site (Melo $\&$ Froenlich 2001a). Other macroinvertebrate groups present in streams are crustaceans, mollusks and planarians. Many stream macroinvertebrates present low tolerance to human-induced disturbance and thus are widely used in biomonitoring programs (BARbour et al. 1999, BAptista et al. 2007, Couceiro et al. 2007, Tupinambás et al. 2007).

The relationship between community structure and environmental factors usually varies according to ecosystem type, group of organism and spatial scale (WU \& LoucKs 1995). In stream ecosystems, Vilella et al. (2004) evaluated a range of environmental factors and concluded that stream megafauna (amphibians, crustaceans and fishes) were most affected by structural environmental factors, particularly the presence of waterfalls. In small scales (e.g. microhabitat), stream macroinvertebrates communities can differ due to differences in substrate composition (KIKUCHI \& UIEDA 1998, Buss et al. 2004), availability of food resources (DOBSON 1999, BüCKER et al. 2008) and flow velocity (BOUCKAert \& DAvis 1998, Crisci-Bispo et al. 2007a). In higher spatial scales, differences in macroinvertebrate com- munities among stream sites can result from differences in water chemistry and human or natural disturbances (Diniz-FiLho et al. 1998, Buss et al. 2002, DeATH 2002).

The assessment of the relationships among community structure and candidate environmental factors is not an easy task. Many factors are correlated in space and act simultaneously on species. Given the difficulties to carry out field experiments, most studies addressing the effects of environmental factors on community structure rely on observational approaches (Graham 2003). One suitable method to be used in these observational studies is the BioEnv analytical approach proposed by Clarke \& Ainsworth (1993) that, despite its popularity in marine sciences (the article was cited 484 times until December 2008 in the Science Citation Index), have rarely been used in freshwater ecosystems (but see SOLDNER et al. 2004).

In a previous work, Melo \& Froenlich (2001a) assessed whether macroinvertebrate communities in Neotropical streams conform to predictions of the River Continuum Concept (VAnnote et al. 1980, Minshall et al. 1985). Specifically, they tested the hypotheses that mid-sized streams (orders 3-4) are the richest in the catchment and that communities in the dry season presents higher equilibrium (sensu Minshall et al. 1985) than in the rainy season due to the presence of disturbances by spates in the later. In the present study I extend their findings and, using the same data, assessed which environmental factors best explain differences in dissimilarities among stream sites. 


\section{MATERIAL AND METHODS}

Data were obtained in 10 stream sites of the Rio do Carmo catchment, Parque Estadual Intervales, SP, Brazil $\left(24^{\circ} 18^{\prime} \mathrm{S}\right.$, $48^{\circ} 25^{\prime} \mathrm{W}$ ). The vegetation is tropical ombrophilous sub-montane forest (Atlantic Tropical Rain forest) and remains mostly preserved. The area receives $1500-2000 \mathrm{~mm}$ of rainfall unevenly distributed in two periods, with $130-270 \mathrm{~mm} / \mathrm{mo}$ during the rainy season (summer; September-March) and $60-95 \mathrm{~mm} / \mathrm{mo}$ during and dry (winter; April-August).

Studied streams were of orders 1-5 (Fig. 1) and had the streambed composed mostly by gravel and stones. Stream 3 crosses a calcareous cave and a small swamp. The largest studied stream (10) receives tributaries that pass through calcareous caves. Table I includes information on physical characteristics of the studied stream sites.

Samples were obtained during the dry season of 1997. I obtained 25 sampling units in each stream site. Sampling units consisted of the macroinvertebrate fauna associated to individual stones around $18 \mathrm{~cm}$ maximum diameter. Stones were removed from the streambed using a U-net sampler (Melo \& Froehlich 2001a). The material collected in the net was transferred to a white tray and all visible invertebrates removed and fixed in $80 \%$ ethanol. Stones were examined for attached individuals, particularly cased caddisflies. Additional information on stream sites and sampling, including a list of families, can be found elsewhere (Melo \& Froehlich 2001a, 2004, Crisci-Bispo et al. 2007a, b).

Previous studies on stream macroinvertebrate communities in South America usually have identified individuals to genus or family. This reflects the poor taxonomical knowledge of the aquatic fauna and consequent lack of regional keys. The use of genus and family level identifications has proved to be useful in many cases. This is particularly true when differences among samples are large, such as those observed in the comparisons of stream faunas among biogeographic provinces or in gradients of human-induced disturbance (MARCHANT et al. 1995). However, small differences in community structure among sites can only be detected using species or morphospecies (LenAT \& RESH 2001, also see MeLo 2005). As stream sites are located in the same catchment and do not differ largely in environmental conditions, macroinvertebrates were sorted in morphospecies. Because of difficulties in separation in morphospecies, chironomids and acari were not included.

Sampling units (stones) collected in a stream site were pooled to form a sample. The study thus consisted of 10 samples. Dissimilarities among stream sites were estimated using the Bray-Curtis index on $\log (\mathrm{x}+1)$ transformed samples. This dissimilarity matrix was used to obtain a Non-Metric Multidimensional Scaling (NMDS) ordination of stream sites. The relationship of dissimilarities among stream sites and dissimilarities in environmental factors was assessed using the BioEnv approach (Clarke \& Ainsworth 1993). The approach is related to the Mantel test, where a biological dissimilarity matrix is correlated with a second dissimilarity matrix of environ-

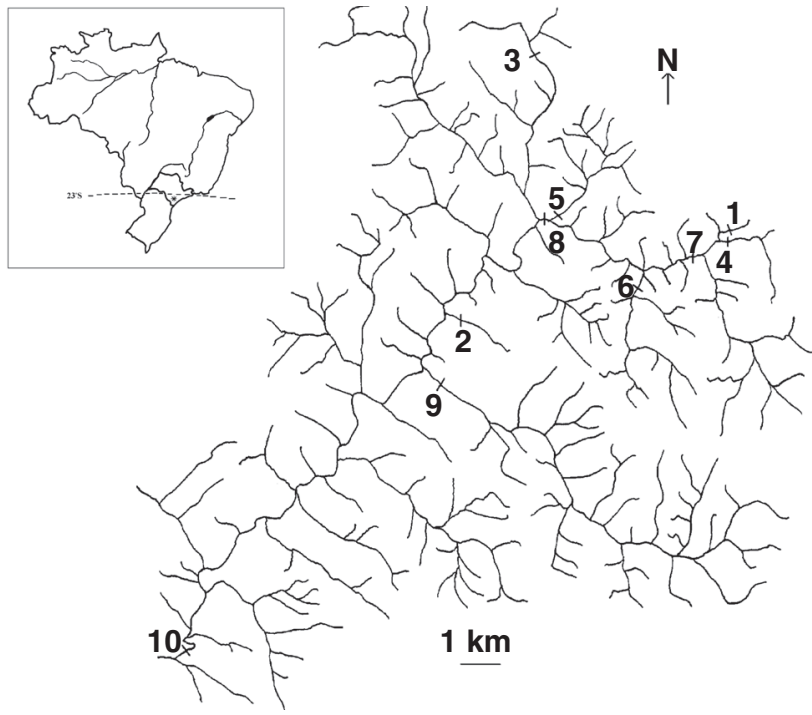

Figure 1. Location of the Rio do Carmo catchment in Brazil and the location of the 10 stream sites studied.

mental variables (Diniz-Filho \& BINI 1996, Diniz-Filho et al. 1998). However, in the BioEnv approach the environmental matrix is constructed using different numbers and combinations of environmental variables. The biological matrix of dissimilarities is first correlated with each environmental dissimilarity matrix obtained using a single variable and the highest correlation selected. Next, the procedure is repeated but now with environmental dissimilarity matrices constructed using two variables. The combination producing the high correlation is selected. The procedure is repeated but using, three, four or more environmental variables up to the total number available, recording in each step the highest correlation. The Spearman rank coefficient was used to measure the correlation of the dissimilarity matrices. The environmental dissimilarities were computed using the Euclidean distance on variables standardized to unit standard deviation. The following variables were used in the BioEnv analysis: I) stream order, II) link magnitude, III) width, IV) baseflow discharge, V) canopy cover, VI) altitude and VII) conductivity (Tab. I).

Different from a linear model (e.g. Multiple Regression), where the correlation of the response with the set of predictors always increase or remains the same as more terms are included in the model, in the BioEnv approach the correlation can decrease after the inclusion of variables. This happens because no additional term is included in the statistical model. Instead, the additional variable can deteriorate the correlation pattern between the biological and environmental dissimilarity matrices. This feature thus provides a natural stopping rule in the selection of the best set of environmental variables. All analyses were done using functions in the packages 'vegan' (ОкsANEN et al. 2008) and 'MASS' (Venables \& Ripley 2002) of the statistical environment R (R Development Core Team 2007). 


\section{RESULTS}

The 10 samples contained 10767 individuals and 142 morphospecies. The NMDS ordination of the samples was effective in the reduction of the data dimensionality (stress 0.07 ) (Fig. 2). The largest stream sites (8, 9 and 10) received high scores in the second axis of the ordination.

The BioEnv analyses indicated that the best correlation was obtained with the dissimilarity matrix built using conductivity, number of stream links and stream order $(r=0.62$, Tab. II). Number of stream links and stream order are correlated $(\mathrm{r}=0.71)$ and thus are mostly redundant. In fact, the model including conductivity and number of stream links produced similar correlation to that including the three variables $(\mathrm{r}=0.59)$. The model including conductivity only resulted in low correlation $(\mathrm{r}=0.46)$, indicating that stream size was important. In fact, the NMDS ordination of the samples assigned high scores in the second axis for the largest stream sites (8, 9 and 10) (Fig. 2 ). The high importance of conductivity is due mostly to the high values observed in site 3 and, to a lesser extent, in site 5 (Tab. I). In the NMDS ordination these two sites received the highest scores in the first axis.

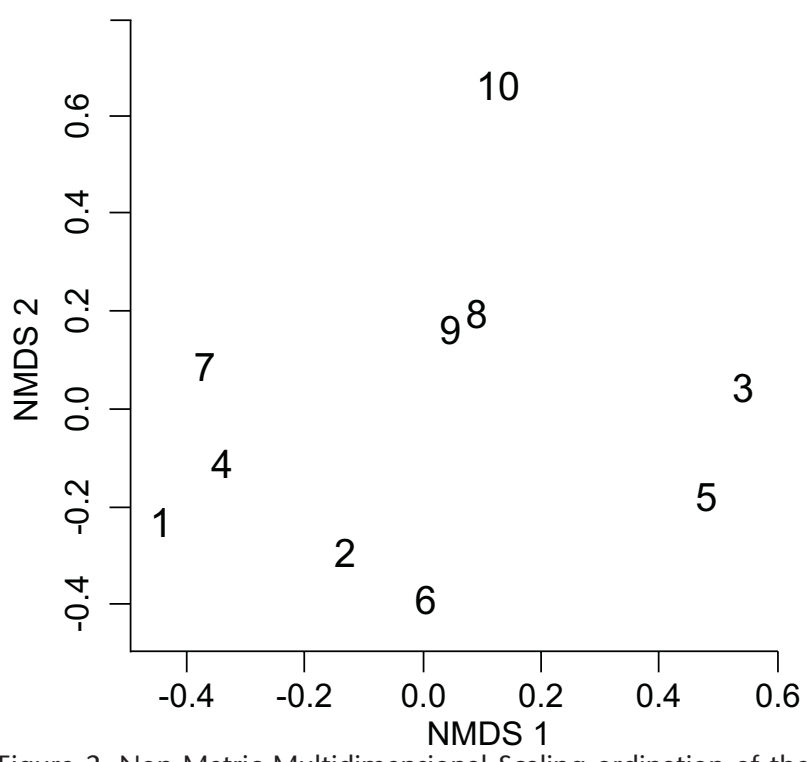

Figure 2. Non-Metric Multidimensional Scaling ordination of the 10 stream sites. Number refers to stream sites shown in figure 1. Stress $=0.07$.

Table I. Physical characteristics of the 10 sampling sites in Parque Estadual Intervales. ${ }^{a}$ Number of first order streams included in the subcatchment; ${ }^{\mathrm{b}}$ Obtained using a Presto-Tek (California, USA) conductivimeter.

\begin{tabular}{|c|c|c|c|c|c|c|c|}
\hline $\begin{array}{l}\text { Stream } \\
\text { sites }\end{array}$ & $\begin{array}{c}\text { Stream } \\
\text { order }\end{array}$ & $\begin{array}{c}\text { Link } \\
\text { magnitude }\end{array}$ & $\begin{array}{l}\text { Width } \\
(\mathrm{m})\end{array}$ & $\begin{array}{c}\text { Discharge } \\
\left(\mathrm{m}^{3} / \mathrm{s}\right)\end{array}$ & $\begin{array}{c}\text { Canopy cover } \\
(\%)\end{array}$ & $\begin{array}{c}\text { Altitude } \\
\mathrm{m})\end{array}$ & $\begin{array}{c}\text { Condutictivity } \\
(\mu \mathrm{s} / \mathrm{cm})^{\mathrm{b}}\end{array}$ \\
\hline 1 & 1 & 1 & 1.0 & 0.005 & 100 & 680 & 51 \\
\hline 2 & 1 & 1 & 2.5 & 0.010 & 100 & 540 & 33 \\
\hline 3 & 2 & 3 & 2.5 & 0.030 & 94 & 800 & 180 \\
\hline 4 & 2 & 2 & 3.5 & 0.059 & 100 & 680 & 48 \\
\hline 5 & 3 & 11 & 2.5 & 0.137 & 98 & 530 & 63 \\
\hline 6 & 3 & 6 & 4.0 & 0.092 & 98 & 700 & 45 \\
\hline 7 & 4 & 15 & 6.0 & 0.238 & 90 & 650 & 40 \\
\hline 8 & 4 & 43 & 10.0 & 0.657 & 94 & 520 & 30 \\
\hline 9 & 4 & 36 & 10.0 & 0.750 & 84 & 400 & 36 \\
\hline 10 & 5 & 175 & 21.0 & 2.729 & 72 & 200 & 75 \\
\hline
\end{tabular}

Table II. Results of the BioEnv analysis for samples collected in 10 stream sites in the Parque Estadual Intervales. (alt) Altitude, (cond) conductivity, (cover) canopy cover, (flow) discharge, (links) link magnitude, (order) stream order, (width) stream width. Units of variables can be found in table I. Correlation for the best model shown in bold.

\begin{tabular}{clc}
\hline Model size & \multicolumn{1}{c}{ Model } & Correlation \\
\hline 1 & cond & 0.4570 \\
2 & cond + links & 0.5887 \\
3 & cond + links + order & 0.6190 \\
4 & cond + links + order + width & 0.6030 \\
5 & cond + links + order + width + flow & 0.5906 \\
6 & cond + links + order + width + flow + alt & 0.5657 \\
7 & cond + links + order + width + flow + alt + cover & 0.5149 \\
\hline
\end{tabular}




\section{DISCUSSION}

The results agree with previous works that indicated the importance of stream size and conductivity for the macroinvertebrate fauna (Froendich \& Oliveira 1997, Strieder 2002). For instance, VANNOTE et al. (1980) predicted a continuous change in relative importance of functional feeding groups along a stream size gradient (BAPTISTA et al. 1998b). SOLDNER et al. (2004) evaluated the effects of a range of environmental variables on macroinvertebrate fauna in 26 streams in the Dominican Republic. They found that altitude (a proxy for temperature and stream size), percentage of sand/silt and average chemical rank (a metric composed of conductivity, hardness, $\mathrm{NH}_{4}, \mathrm{NO}_{3}, \mathrm{PO}_{4}$ and dissolved oxygen) were among the most important factors, but stated that such findings may be confounded by human impacts in lowland sites. In Brazil, BAPTISTA et al. (2001) studied the macroinvertebrate fauna in 10 stream sites (orders 1-6) in Macaé River catchment and found that conductivity and stream size were among the most important environmental variables structuring assemblages.

The largest stream site (site 10, order 5) presented a relatively distinct assemblage and was scored far from the remaining stream sites in the NMDS ordination. This was the single $5^{\text {th }}$ order stream in the study and thus only weak generalizations are possible. However, previous studies have also shown an abrupt change in macroinvertebrates assemblages among $4^{\text {th }}$ and $5^{\text {th }}$ order streams. For instance, Hynes (1971) presented a similar result in table I of his zonation study in a Neotropical stream in Trinidad, West Indies. Similarly, Minshall \& Robinson (1998) found abrupt changes in community structure among large ( $>4^{\text {th }}$ order) and small streams. BAPTISTA et al. (2001) showed that $5^{\text {th }}$ order sites presented distinct communities and apparently this was not a result from human activities. PERry \& SCHAEFfer (1987) presented evidence of serial discontinuities in stream assemblages. Statzner \& Higler (1986) suggested that abrupt change in stream assemblages should likely reflect changes in stream hydraulics. Although specific measures of stream hydraulics are not available, the suggestion of STATZNER \& Higler (1986) can only in part explain the observed pattern because the sampled site is similar to the $4^{\text {th }}$ order sites in terms of slope and substrate size and composition. Differences in relation to $4^{\text {th }}$ order sites are restricted to discharge, width and longer pools. These scattered evidences suggest that this abrupt change in community structure between $4^{\text {th }}$ and $5^{\text {th }}$ order streams is not due to local idiosyncrasies, but a spread pattern. This topic deserves further investigation, not only to test the strength of the pattern but also its generating causes (STATZNER \& Higler 1986).

Despite the high correlation observed among differences in conductivity and dissimilarities in stream assemblages, care should be taken in the interpretation of this result. The high relative importance of conductivity was mostly due to the high value observed in stream site 3 , which receives water from a calcareous cave. This site presented a relatively distinct com- munity and all site pairs including this stream produced high dissimilarities. The observed result is thus based mostly in one stream site, which provides weak evidence for a strong effect of conductivity. However, this weak evidence is corroborated by the study of BAPTISTA et al. (2001), who found that conductivity was among the best environmental factors structuring stream macroinvertebrate assemblages in the Macaé River. A similar case is cited in Allan (1995: 38).

The finding that distinct macroinvertebrate assemblages are present in streams differing in size and conductivity in the same catchment highlights the importance of conservation strategies aimed at the whole drainage basin. However, the current conservation status of the Atlantic Rain Forest poses a challenge for implementation of acts based on such approach.

The Atlantic Rain Forest has long been subjected to intense clearance for human activities (DEAN 1997). Currently, only $5 \%$ of its original area was not destroyed. Most of the remaining Atlantic Rain Forest is constituted by small fragments and large areas are restricted to steep terrain (OLIVEIRA-FilHo \& Fontes 2000). Accordingly, few of these fragments are large enough to harbor whole catchments including small- or medium-sized rivers $\left(>4^{\text {th }}\right.$ order). This implies the urgency of restoration programs in areas adjacent to Atlantic Rain Forest fragments.

\section{ACKNOWLEDGEMENTS}

José Flóido, Elias Mota, Benedito Amaral, Eliseu Cordeiro, Faustino Ribeiro, Luiz Ribeiro, Fábio Vanini, Anders Silva, Kátia Pisciotta, and the Intervales staff provided helpful assistance and facilities during field work. Field work was facilitated by a student fellowship from CAPES. I was supported by grants from CNPq (proccess 476304/2007-5) and International Foundation for Science (A/4107-1) during the preparation of the manuscript. This work is part of the BIOTA/FAPESP - The Biodiversity Virtual Institute Program (www.biota.org.br).

\section{LITERATURE CITED}

Allan, J.D. 1995. Stream Ecology. Structure and function of running waters. London, Chapman \& Hall,.XII+388p.

Baptista, D.F.; L.F.M. Dorvillé; D.F. Buss; J.L. Nessimian \& L.H.J. SOARES. 1998a. Distribuição de comunidades de insetos aquáticos no gradiente longitudinal de uma bacia fluvial do sudeste brasileiro, p. 191-207. In: J.L. Nessimian \& J.L. CarvaLHO (Eds). Ecologia de insetos aquáticos. Rio de Janeiro, PPGE-UFRJ, XVII+309p.

Baptista, D.F.; D.F. Buss; L.F.M. Dorvillé \& J.L. Nessimian. 1998b. O conceito de continuidade de rios é válido para rios de Mata Atlântica no sudeste do Brasil?, p. 209-222. In: J.L. Nessimian \& J.L. Carvalho (Eds). Ecologia de insetos aquáticos. Rio de Janeiro, PPGE-UFRJ, XVII+309p.

Baptista, D.F.; L.F.M. Dorvillé; D.F. Buss \& J.L. Nessimian. 2001. Spatial and temporal organization of aquatic insects assemblages in the longitudinal gradient of a tropical river. Revista Brasileira de Biologia 61 (2): 295-304. 
Baptista, D.F.; D.F. Buss; M. Egler; A. Giovanelli; M.P. Silveira \& J.L. Nessimian. 2007. A multimetric inex based on benthic macroinvertebrates for evaluation of Atlantic Forest streams at Rio de Janeiro State, Brazil. Hydrobiologia 575: 83-94.

Barbour, M.T.; J. Gerritsen; B.D. Snyder\& J.B. Stribling. 1999. Rapid Bioassessment Protocols for Use in Streams and Wadeable Rivers: Periphyton, Benthic Macroinvertebrates and Fish. Washington, U.S. Environmental Protection Agency, Office of Water, $2^{\text {nd }}$ ed., XIV+322p.

Bouckaert, F.W. \& J. Davis. 1998. Microflow regimes and the distribution of macroinvertebrates around stream boulders. Freshwater Biology 40: 77-86.

Bücker, F.; R. Gonçalves; G. Bond-Buckup \& A.S. Melo. 2008. Effect of environmental variables on the distribution of two freshwater crabs (Anomura: Aeglidae). Journal of Crustacean Biology 28 (2): 248-251.

Buckup, L.; A.A.P. Bueno; G. Bond-Buckup; M. Casagrande \& F. Majolo. 2007. The benthic macroinvertebrate fauna of highland streams in southern Brazil: composition, diversity and structure. Revista Brasileira de Zoologia 24 (2): 294-301.

Bueno, A.A.P; G. Bond-Buckup \& B.D.P. Ferreira. 2003. Estrutura da comunidade de invertebrados bentônicos em dois cursos d'água do Rio Grande do Sul, Brasil. Revista Brasileira de Zoologia 20 (1): 115-125.

Buss, D.F.; D.F. Baptista; M.P. Silveira; J.L. Nessimian \& L.F.M. Dorvillé. 2002. Influence of water chemistry and environmental degradation on macroinvertebrate assemblages in a river basin in south-east Brazil. Hydrobiologia 481: 125-136.

Buss, D.F.; D.F. Baptista; J.L. Nessimian \& M. EgLer. 2004. Substrate specificity, environmental degradation and disturbance structuring macroinvertebrate assemblages in neotropical streams. Hydrobiologia 518: 179-188.

Clarke, K.R \& M. Ainsworth. 1993. A method of linking multivariate community structure to environmental variables. Marine Ecology Progress Series 92: 205-219.

Couceiro, S.R.M.; N. Hamada; S.L.B. Luz; B.R. Forsberg \& T.P. Pimentel. 2007. Deforestation and sewage effects on aquatic macroinvertebrates in urban streams in Manaus, Amazonas, Brazil. Hydrobiologia 575: 271-284

Crisci-Bispo, V.L.; P.C. Bispo \& C.G. Froenlich. 2007a. Ephemeroptera, Plecoptera and Trichoptera assemblages in litter in a mountain stream of the Atlantic Rainforest from Southeastern Brazil. Revista Brasileira de Zoologia 24 (3): 545-551.

Crisci-Bispo, V.L.; P.C. Bispo \& C.G. Froehlich. 2007b. Ephemeroptera, Plecoptera and Trichoptera assemblages in two Atlantic Rainforest streams, Southeastern Brazil. Revista Brasileira de Zoologia 24 (2): 312-318.

DeAn, W. 1997. A ferro e fogo. A história e a devastação da Mata Atlântica Brasileira. São Paulo, Companhia das Letras, 484p.

Death, R.G. 2002. Predicting invertebrate diversity from disturbance regimes in forest streams. Oikos 97 (1): 18-30.

Diniz-Filho, J.A.F. \& L.M. Binı. 1996. Assessing the relationship between multivariate community structure and environmental variables. Marine Ecology Progress Series 143: 303-306.

Diniz-Filho, J.A.F.; L.G. Oliveira \& M.M. Silva. 1998. Explaining the beta diversity of aquatic insects in "cerrado" streams from central Brazil using multiple Mantel test. Revista Brasileira de Biologia 58 (2): 223-231.

Dobson, M. 1999. Aggregation of Potamophylax cingulatus (Trichoptera: Limnephilidae) larvae in response to possible food limitation in a southern French stream. Archiv für Hydrobiologie 145 (3): 317-329.

Froehlich, C.G. \& L.G. Oliveira. 1997. Ephemeroptera and Plecoptera nymphs from riffles in low-order streams in southeastern Brazil, p. 180-185. In: P. LANDOLT \& M. SARTORI (Eds). Ephemeroptera and Plecoptera: biology-ecologysystematics. Fribourg, Mauron, Tinguely \& Lanchat, XI+569p.

Graham, M.H. 2003. Confronting multicollinearity in ecological multiple regression. Ecology 84 (11): 2809-2815.

HyNES, H.B.N. 1971. Zonation of the invertebrate fauna in a West Indian stream. Hydrobiologia 38 (1): 1-8.

Kikuchi, R.M. \& V.S. Uieda. 1998. Composição da comunidade de invertebrados de um ambiente lótico tropical e sua variação espacial e temporal, p. 157-173. In: J.L. Nessimian \& J.L. Carvalho (Eds) Ecologia de Insetos Aquáticos. Rio de Janeiro, PPGE-UFRJ, XVII+309p.

Lenat, D.R. \& V.H. Resh. 2001. Taxonomy and stream ecology - The benefits of genus- and species-level identifications. Journal of the North American Benthological Society 20 (2): 287-298.

Marchant, R.; L.A. Barmuta \& B.C. Chessman. 1995. Influence of sample quantification and taxonomic resolution on the ordination of macroinvertebrate communities from running waters in Victoria, Australia. Marine and Freshwater Research 46: 501-506.

Melo, A.S. 2005. Effects of taxonomic and numeric resolution on the ability to detect ecological patterns at a local scale using stream macroinvertebrates. Archiv für Hydrobiologie 164 (3): 309-323.

Melo, A.S. \& C.G. Froehlich. 2001a. Macroinvertebrates in neotropical streams: richness patterns along a catchment and assemblage structure between 2 seasons. Journal of the North American Benthological Society 20 (1): 1-16.

Melo, A.S. \& C.G. Froenlich. 2001b. Evaluation of methods for estimating macroinvertebrates species richness using individual stones in tropical streams. Freshwater Biology 46 (6): 711-721.

Melo, A.S. \& C.G. Froehlich. 2004. Colonization by macroinvertebrates of experimentally disturbed stones in three tropical streams differing in size. International Review of Hydrobiology 89 (3): 317-325.

Minshall, G.W. \& C.T. Robinson. 1998. Macroinvertebrate community structure in relation to measures of lotic habitat heterogeneity. Archiv für Hydrobiologie 141 (2): 129-151.

Minshall, G.W.; R.C.J. Petersen \& C.F. Nimz. 1985. Species richness in streams of different size from the same drainage basin. The American Naturalist 125 (1): 16-38. 
Oksanen, J.; R. Kindt; P. Legendre; R.B. O'Hara; G.L. Simpson \& M.H.H. Stevens. 2008. vegan: Community Ecology Package. R package version 1.13-0, available online at: http://vegan.rforge.r-project.org [Accessed: 30/XII/2008]

Oliveira-Filho, A.T. \& M.A.L. Fontes. 2000. Patterns of floristic differentiation among Atlantic Forests in Southeastern Brazil and the influence of climate. Biotropica 32 (4b): 793-810.

Perry, J.A. \& D.J. Schaeffer. 1987. The longitudinal distribution of riverine benthos: A river dis-continuum? Hydrobiologia 148: 257-268.

R Development Core Team. 2007. R: A language and environment for statistical computing. Vienna, R Foundation for Statistical Computing, ISBN 3-900051-07-0, available online at: http://www.R-project.org [accessed: 30/XII/2008]

Soldner, M.; I. Stephen; L. Ramos; R. Angus; N.C. Wells; A. Grosso \& M. Crane. 2004. Relationship between macroinvertebrate fauna and environmental variables in small streams of the Dominican Republic. Water Research 38: 863-874.

Statzner, B. \& B. Higler. 1986. Stream hydraulics as a major determinant of benthic invertebrate zonation patterns. Freshwater
Biology 16: 127-139.

Strieder, M.N. 2002. Diversidade e distribuição de Simuliidae (Diptera, Nematocera) no gradiente longitudinal da bacia do Rio Maquiné, RS, Brasil. Biociências 10 (1): 127-137.

TupinambÁs, T.H.; M. Callisto \& G.B. SAnTos. 2007. Benthic macroinvertebrate assemblages structure in two headwater streams, south-eastern Brazil. Revista Brasileira de Zoologia 24 (4): 887-897.

Venables, W.N. \& B.D. Ripley. 2002. Modern Applied Statistics with S. New York, Springer, $4^{\text {th }}$ ed., XI+495p.

Vilella, F.S.; F.G. Becker; S.M. Hartz \& G. Barbieri. 2004. Relation between environmental variables and aquatic megafauna in a first order stream of the Atlantic Forest, southern Brazil. Hydrobiologia 528: 17-30.

Vannote, R.L.; G.W. Minshall; K.W. Cummins; J.R. Sedell \& C. Cushing. 1980. The river continuum concept. Canadian Journal of Fisheries and Aquatic Sciences 37: 130-137.

Wu, J. \& O.L. Loucks. 1995. From balance of nature to hierarchical patch dynamics: a paradigm shift in ecology. The Quarterly Review of Biology 70 (4): 439-466.

Submitted: 15.VII.2008; Accepted: 09.III.2009.

Editorial responsibility: Paulo Lana 